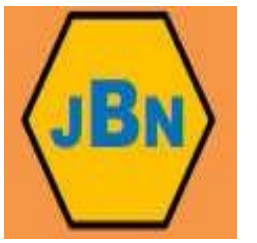

\title{
PEMBERDAYAAN MASYARAKAT DESA JERINGO MELALUI PENERAPAN TEKNOLOGI PEMBUATAN BATAKOBERPENGUAT SERAT IJUK
}

\author{
Sujita ${ }^{1}$, Achmad Zainuri ${ }^{1}$, IGAK Chatur Adhi W.A ${ }^{1}$, Nur Kaliwantoro ${ }^{1}$, Sultan ${ }^{2}$ \\ Email:suiita@unram.ac.id \\ 1JurusanTeknik Mesin, Fakultas Teknik, Universitas Mataram \\ 2Jurusan Teknik Elektro, Fakultas Teknik, Universitas Mataram
}

\author{
Revised: 02 Maret 2021 \\ Accepted: 04 Maret 202
}

Corresponding author: Sujita, Jurusan Teknik Elektro,Universitas Mataram, Email: sujita@unram.ac.id

\begin{abstract}
ABSTRAK
Desa Jeringo adalah salah satu desa di wilayah Kabupaten Lombok Barat,yang masyarakatnya rata-rata hidup dibawah garis kemiskinan dan jumlah penganggurannya terbanyak, akibat dampak pemulangan TKI yang bekerja di Malaysia. Penduduk di daerah ini mata pencahariannya adalah sebagai penyadap aren, membuat kerajinan dari ijuk (sapu, keset) dan penambang pasir, batu kerikil di sungai yang mengalir sepanjang Dusun Jeringo, Mambalan dan Guntur Macan. Tujuan khusus dari kegiatan KKN-PPM yang telah dilaksanakan adalah untuk mengatasi masalah yang berkaitan dengan kurangnya ketersediaan material bahan bangunan/batako, rendahnya pendapatan masyarakat dan pengelolaan sumber daya alam belum optimal.. Metode yang digunakan adalah dengan menerapkan secara langsung teknologi pembuatan batako berpenguat serat ijuk. kepada khalayak sasaran mitra KKN-PPM Desa Jeringo Kecamatan Gunungsari. Kegiatan KKNPPM yang telah dilaksanakan selama 2.5 bulan. Berdasarkan hasil kegiatan, penambahan $5 \%$ serat ijuk pada adonan batako akan memberikan kualitas yang maksimal pada batako, daya ikat antara ijuk dan adonan (pasir, semen) seragam dan kekuatan tekan rata-rata mencapai $135 \mathrm{Kg}$. Batako tanpa penguat ijuk kekuatan tekan rata-ratanya lebih rendah yaitu sekitar $90 \mathrm{Kg}$.
\end{abstract}

Kata Kunci:batako, serat penguat, serat ijuk, kualitas, kapasitas.

\begin{abstract}
Jeringo village is one of the villages in the area of West Lombok Regency, West Nusa Tenggara Province where the average population lives below the poverty line and has the most unemployment, due to the impact of returning migrant workers who work in Malaysia. Residents in this area are livelihoods as palm sugar tapers, making handicrafts from palm fibers (brooms, doormats) and sand miners, gravel stones in rivers that run along Jeringo, Mambalan and Guntur Macan. The specific purpose of the KKN-PPM activities that will be carried out is to overcome problems related to the lack of availability of building materials / concrete blocks, the low income of the people, the management of natural resources is not yet optimal. The method used by directly applying the technology of making fibers reinforced palm fibers. to the target audience of KKN-PPM partners Jeringo Village, Gunungsari District. KKN-PPM activities that carried out for 2.5 months, are carried out by 30 student participants and are guided by Field Supervisors. Based on the activity addition of 5\% palm fibers to the batako mixture will give maximum quality to the concrete block, the bonding capacity between the fibers and the mixture (sand, cement) is uniform and the average compressive strength reaches $135 \mathrm{~kg}$, the brick without reinforcement fibers lower average compressive strength of $90 \mathrm{~kg}$.
\end{abstract}

Keywords:brick, fiber reinforcement, palm fibers, quality, capacity.

\section{PENDAHULUAN}

Pemerintah daerah NTB mengambil langkah strategis dalam dengan jalan menciptakan peluang kerja bagi tenaga kerja produktif dengan bekerja sama dengan pihak perguruan tinggi. Dalam rangkamengurangi angka pengangguran, sebagai dampak langsung dari pemulangan TKI dari negara Malaysia. Kebijaksanaan yang diambil berdasarkan potensi wilayah setempat dan peluang pasar yang ada. Desa Jeringo adalah salah satu desa di wilayah Kabupaten Lombok Barat, Propinsi Nusa Tenggara Barat yang masyarakatnya rata-rata hidup dibawah 
garis kemiskinan [1] dan jumlah penganggurannya terbanyak, akibat dampak pemulangan TKI yang bekerja di Malaysia. Penduduk di daerah ini mata pencahariannya adalah sebagai penyadap aren, membuat kerajinan dari ijuk (sapu, keset) dan penambang pasir, batu kerikil di sungai yang mengalir sepanjang Dusun Jeringo, Mambalan dan Guntur Macan. Kegiatan penambangan pasir dilakukan secara secara berkelompok (5 orang). Biasanya dalam satu hari mereka, dapat mengumpulkan pasir dua $20 \mathrm{~m}^{3}$, dengan pengasilan rata-rata setiap harinya hanya Rp 40.000,- per orang. Sedangkan penyadap enau dan pengrajin ijuk penghasilannya tidak menentu.Kegiatan ini hanya dilakukan oleh para orang tua, sedangkan bagi pemuda (usia produktif)rata-ratamerantausebagai TKI ke Malaysia. Sebenarnya daerah ini sangatberpotensi untuk dikembangkan. Posisinya sangat strategis (dekat Kota Mataram, Pantai Sengigi, BTN Jeringo Permai, BTN Montong Kedaton, BTN Gunungsari). Sumber kekayaan alamnya melimpah, pasir, batu koral (dekat aliran sungai Meninting), pohon aren (dengan hasil sampingan ijuk). Berdasarkan data Dinas Perkebunan dan Kehutanan Lombok Barat, luas areal pohon aren yang produktif $203 \mathrm{Ha}$ [2]. Tetapi pemanfaatan hasilnya belum optimum, hanya sebagai bahan sapu ijuk, keset dan disadap (untuk menghasilkan tuak manis/legen).Di sisi lain wilayah ini masih harus mendatangkan material bahan bangunan sepertibatako dan bata dari daerah lain. Sehingga menganggu perkembangan pembangunan pemukiman/perumahan di wilayah tersebut.Batako di daerah ini mahal misalnya batako lokal (Buatan Kumbung), mencapai harga Rp 2.500,- per biji, batako (buatan Dasan Cermen) Rp 2.250.000,- [3] . Batako yang ada sekarang berdasarkan pemantauan di lapangan kualitasnya masih rendah: mudah pecah, kekuatan tekannya tidak memenuhi standart (berdasarkan SII NO.0447 kekuatan tekanya adalah $60 \mathrm{Kg}$ untuk kelas II dan $150 \mathrm{Kg}$ untuk kelas I). Peluang pasar untuk batako sangat baik, mengingat di daerah ini sedang dikembangkan/dibukaperumahan BTN baru, hotel dan pemukiman penduduk. Melihat peluang pasar yang ada, maka daerah sangat cocok dikembangkan sebagai daerah pembuatan batako berpenguat serat ijuk, mengingat ketersediaan sumber daya alam pasir dan ijuk sangat melimpah. Untuk mengatasi masalah yang berkaitan dengan kurangnya ketersediaan materialbahan bangunan/batako, rendahnya pendapatan masyarakat, pengelolaan sumber daya alam belum optimal dan peluang pasar produk batako yang masih terbuka, maka dilakukan kegiatan berupa penerapan teknologi pembuatan batako berpenguat serat ijuk. Pasir dan ijuk yang melimpah akan dimodifikasi menjadi produk yang bernilai ekonomi tinggi, melalui kegiatan Kuliah Kerja Nyata Pemberdayaan dan Pembelajaran (KKN-PPM) selama 2.5 bulan. Batako berpenguat ijuk yang akan diterapkan merupakan hasil penelitian Fakultas Teknik Mesin Universitas Atmajaya Yogyakarta. Berdasarkan penelitian [4],penambahan 5\% serat ijuk pada adonan batako akan memberikan kualitas yang maksimal pada batako, daya ikat antara ijuk dan adonan (pasir, semen) seragam dan kekuatan tekan rata-rata mencapai $135 \mathrm{Kg} / \mathrm{cm}^{2}$. Selanjutnya berdasarkan penelitia [6], batako tanpa penguat ijuk kekuatan tekan rata-rata $90 \mathrm{Kg} / \mathrm{cm}^{2}$. Lembaga mitra kegiatan KKN-PPM adalah pemerintahan Desa Jeringo Kecamatan Batulayar Kabupaten Lombok Barat, dengan khalayak sasaran dari kegiatan KKN-PPM adalah: warga dusun Perempung, Midas dan Kayangan, Desa Jeringo yang berprofesi sebagai penambang pasir, penyadap enau/pembuat tuak manis, kesed dan sapu dari pohon enau dan pemuda desa usia produktif.Dengan meningkatkanpemberdayaan masyarakat melalui kegiatan KKN-PPM diharapkan akan menambah lapangan kerja (mengurangi pengangguran) dan meningkatkan pendapatan khalayak sasaran

\section{METODE}

Metode pelaksanaan kegiatan KKN-PPM yang sudah dilaksanakan sebagai solusi pemecahan masalah adalah sebagai berikut:

1. Persiapan dan Pembekalan.

a. Mekanisme pelaksanaan kegiatan KKN-PPM

Penyelenggaraan KKN-PPM dikoordinasikan oleh Ketua LPPM Unram dan dilaksanakan oleh Tim pengusul KKN-PPM. Dalam pengelolaan KKN-PPM agar berjalan dengan baik Ketua LPPM Unram dibantu oleh Sekretaris, Bendahara dan 4 Divisi (Divisi Kesekretariatan, Kerjasama dan Pengembangan Tema, Operasional dan Monitoring, Pembekalan dan Evaluasi). Peserta KKN-PPM adalah mahasiswa dengan persyaratan sebagai berikut:

- Terdaftar sebagai mahasiswa program S1 
- Telah merencanakan KKN pada KRS

- Telah menempuh SKS minimal 108 SKS tanpa nilai E

b. Materi Persiapan dan pembekalan KKN-PPM yang perlu diberikan kepada mahasiswa

- Tim Pusat Layanan KKN-PPM (LPPM Unram) mengidentifikasi beberapa desa sebagai desa binaan. Salah satu desa binaan (Desa Sandik Kecamatan Batulayar).

- Petugas Lapangan KKN-PPM menentukan tema kegiatan sesuai dengan bidang keahlian (Fakultas, Jurusan/Program Studi). Tema yang diajukan dalam kegiatan KKN-PPM ini adalah: Penerapan Teknologi Tepat Guna, dengan Bidang kegiatan Peningkatan Produksi dan Nilai Tambah.

- LPM Unram menginformasikan KKN-PPM ke mahasiswa melalui Fakultas/Jurusan dilingkungan Unram

c. Pembekalan.

- Mahasiswa peserta KKN-PPM wajib mengikuti pembekalan materi KKN-PPM yang memiliki bobot 1 sks, dengan waktu pelaksanaan 800 menit (1 SKS x 50 menit x16 kali) setara dengan 14 jam termasuk kegiatan terstruktur dan mandiri

- Pembekalan dilakukan selama 2 hari termasuk evaluasi.

- Materi pembekalan meliputi : pengenalan teknologi pembuatan batako berpenguat ijuk sebagai material bangunan, dimensi standart batako, cara pembuatan cetakan batako, kebutuhan peralatan yang digunakan, cara pembuatan adonan pembuatan batako berpenguat ijuk, analisa ekonomi (Break Event Poin/BEP) usaha pembuatan batako.

2. Pelaksanaan.

Tahap pelaksanaan ini berbobot 3 SKS dengan lama waktu pelaksanaan 432-504 jam (3 SKS x 6-7 jam kerja per hari x 24 kali)setaradengan75hariatau 2,5 bulan dilokasi KKN.

\section{POTENSI TEMPAT PENGABDIAN}

Desa Jeringo sangatpotensial untuk dikembangkan.Posisinya sangat strategis (dekat Kota Mataram, Pantai Sengigi, BTN Jeringo Permai, BTN Montong Kedaton, BTN Gunungsari). Sumber kekayaan alamnya melimpah, pasir, batu koral (dekat aliran sungai Meninting), pohon aren (dengan hasil sampingan ijuk). Berdasarkan data Dinas Perkebunan dan Kehutanan Lombok Barat, luas areal pohon aren yang produktif, $203 \mathrm{Ha}$ (Dinas Pertanian dan Perkebunan Lobar, 2018). Tetapi pemanfaatan hasilnya belum optimum, hanya sebagai bahan sapu ijuk, keset dan disadap (untuk menghasilkan tuak manis/legen).Di sisi lain wilayah ini masih harus mendatangkan material bahan bangunan sepertibatakodanbata daridaerah lain. Sehingga mengangguperkembanganpembangunanpemukiman/perumahandiwilayah tersebut. Batako di daerah ini mahal misalnya batako lokal (Buatan Kumbung), mencapai harga Rp 2.500,- per biji, batako (buatan Dasan Cermen) Rp 2.250.000,-.

\section{HASIL DANPEMBAHASAN}

Hasil dari kegiatan KKN-PPMyang sudah terlaksana seperti terlihat pada Gambar 1. adalahsebagai berikut:

- Sosialisasi Program.

Melakukan sosialisasi program yang telah direncanakan sebelumnya yang merupakan gagasan bersama (co creation) antara pihak universitas (dosen, mahasiswa) dan pihak mitra.

- Rencana Kegiatan.

Menyusun rencana kegiatan berdasarkan tema, yang memuat nama program kegiatan, bahan, volume, waktu dan sumber dana.

- Pelaksanaan Kegiatan.

Sosialisasi ke lapangan (mitra), Persiapan, Pelatihan/penyuluhan pembuatan Batako berpenguat serat ijuk, praktek pembuatan cetakan batako, praktek pembuatan batako berpenguat serat ijuk, evaluasi.

- Pengarahan Pembimbingan dan Pengawasan Pelaksanaan KKN-PPM.

- Penarikan Mahasiswa dari Lokasi KKN-PPM.

- Pembuatan Laporan.

- Penilaian. 
Penilai terdiri dari Dosen pembekalan, Dosen Pembimbing Lapangan (DPL) dan mitra (stakeholders).

Dengan menerapkan secara langsung teknologi pembuatan batako berpenguat serat ijuk mengacu pada hasil penelitian yang telah dilakukan sebelumnya kepada kahlayak sasaran mitra KKN-PPM. Kegiatan yang akan dilaksanakan selama 2,5 bulan, untuk mencapai tujuan yang akan diharapkan yaitu, meningkatkan produk batako dan mengolah pasir dan ijuk menjadi batako yang bernilai ekonomi lebih tinggi, sehingga bisa mengurangi pengangguran dan meningkatkan pendapatan khalayak sasaran. Adapun tahapan kegiatan yang sudah dilakukan adalah sebagai berikut:

a. PembuatanCetakanBatako.

Alat ini merupakan bagian pokok untuk pembuatan batako, yang terdiri dari kerangka cetakan samping, cetakan bawah, cetakan atas dan sistem pengikat (mur dan baut). Ukuran cetakan batako standart (p.l.t) adalah $(30 \times 15 \times 10) \mathrm{cm}^{3},[5]$

Bahan dan Alat:

- Besi Profil U sebagai rangka,

- Plat baja,

- Pir/spring,

- Poros baja,

- Mur dan Baut,

- Mesin Las, Gergaji, gerenda, bor dan mesin bubut.

Pembuatan komponen atau bagian dari cetakan batako dilakukan di Laboratorium Proses Produksi Jurusan Teknik Mesin Unram. Di lokasi kegiatan tinggal merangkai/assembly di hadapan para khalayak sasaran.

b. Membuat Batako Berpenguat ljuk.

Bahan dan Alat.

Bahan yang diperlukan untuk kapasitas produk 160 buah/hari adalah sebagai berikut:

- Pasir $0.5 \mathrm{~m} 3$.

- Semen 2 zak.

- ljuk $2 \mathrm{Kg}$

- Saringan pasir

- Parang .

- Plastik.

- Kotak pencampuran.

Pembuatan batako berpenguat serat ijuk secara garis besar dibagi menjadi enam tahap, meliputi:

- Tahap I : Membuat adonan.

- Tahap II : Pencetakkan.

- Tahap III : Penekanan

- Tahap IV : Penghalusan.

- Tahap V : Pengeringan

Kegiatan mahasiswa dalam kegiatan KKN-PPM dinyatakan dalam bentuk Jam Kerja Efektif Mahasiswa (JKEM) seperti ditunjukkan pada Tabel 1. Setiap mahasiswa harus melakukan pekerjaan sebanyak 144 JKEM selama minimal 1 bulan kegiatan. Volume total pekerjaan adalah $\mathrm{n} \times$ y JKEM, dimana $\mathrm{n}$ adalah jumlah mahasiswa yang akan diterjunkan dalam KKNPPM dimaksud; $y$ adalah rata-rata JKEM. 

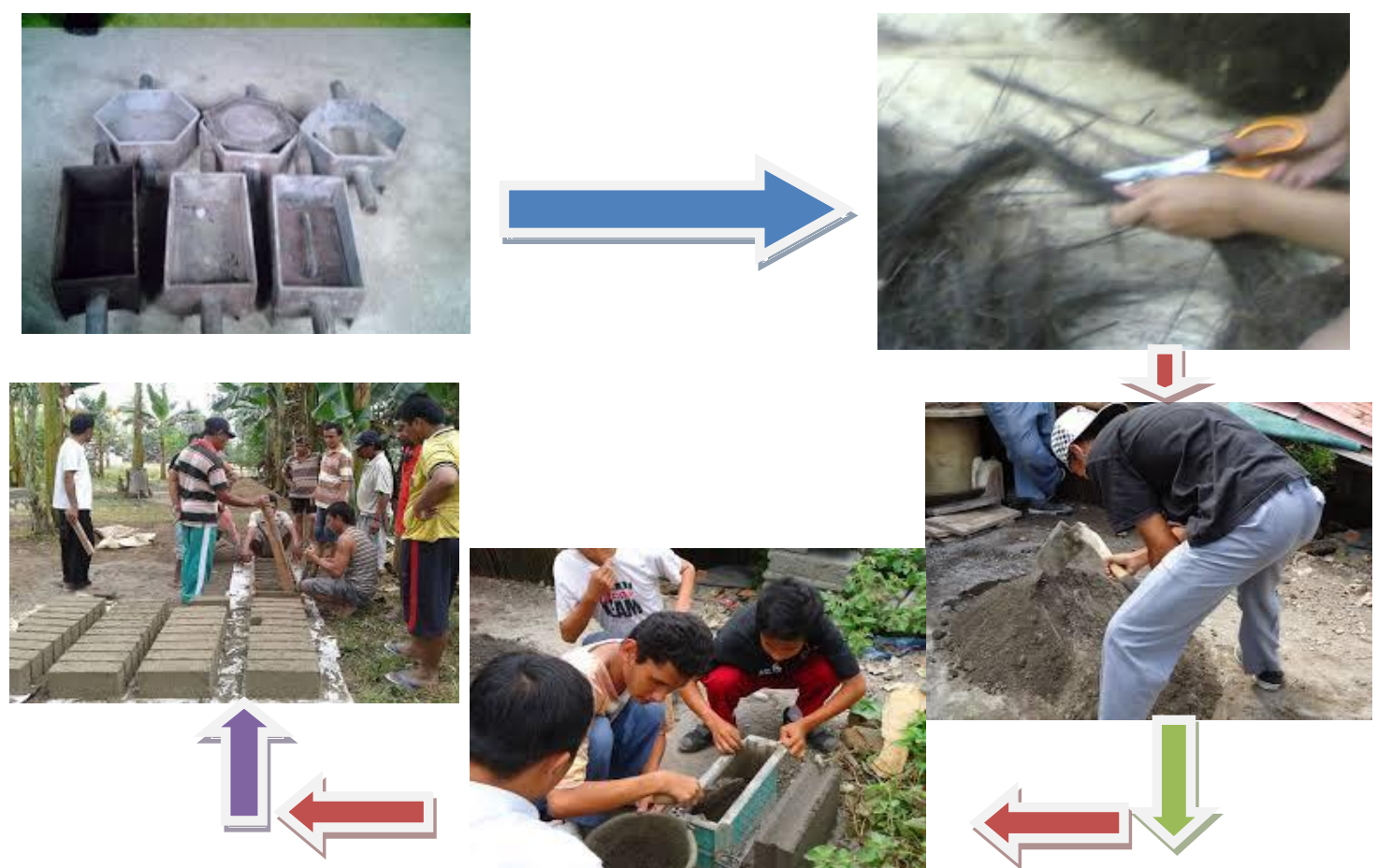

Gambar 1. Kegiatan KKN PPM Pembuatan Batako Pembuatan Batako Berpenguat Serat ljuk

\section{KESIMPULAN}

Kegiatan KKN PPM berupa penerapan teknologi tepat guna pada industri kecil perlu diintensifkan.Karena dengan kegiatan tersebut akan membantu pengusaha dalam memecahkan permasalahan produksi. Dalam hal ini penerapan teknologi berupa penerapan serat ijuk sebagai penguatdapat membantu industri mitra dan warga setempat. Batako yang dihasilkankekuatan tekan rata-rata mencapai $135 \mathrm{Kg}$.Batako tanpa penguat ijuk kekuatan tekan rata-ratanya lebih rendah yaitu sekitar90 $\mathrm{Kg}$,sehingga bisa meningkatkankapasitasdan kualitas produksi.

\section{UCAPAN TERIMA KASIH}

Ucapan terima kasih dapat disampaikan pada pihak-pihak yang telah membantu kegiatan pengabdian, khususnya dukungan dana dari Dirjen Dikti dan Masyarakat Desa Jeringo, Kecamatan Gunungsari, Kabupaten Lombok Barat yang telah membantu kegiatan KKN PPM.

\section{DAFTAR REFERENSI}

[1] Anonim, 2018, Kegiatan Sektor Industri Rumah TanggadiWilayah Nusa Tenggara Barat, Dinas Perindustrian dan Perdagangan NTB

[2] Anonim, 2018, Luas Perkebunan Aren yang Produktif, Dinas Pertanian dan Perkebunan Lobar

[3] Anonim, 2018, Sentra Pembuatan Batako, Profil Desa Jeringo, Gunungsari, Lombok Barat.

[4] Agus Wahyono, dkk, 2016, Pengaruh penambahanserat ijuk pada adonan batako terhadap kuat tekan batako, Laporan Kegiatan Penelitian, Fakultas Teknik Mesin Universitas Atmajaya Yogyakarta

[5] Haryoto, 2012, "Membuat Batako ljuk Semen", Panduan Teknologi Tepat Guna, PDII-LIPI

[6] Suprapto Agus, 2018, "Pengaruh Fraksi Volume ljuk Terhadap Kekuatan Tarik dan Keuletan Campuran Pasir Semen Pada Pembuatan Genteng ljuk Semen", Laporan Penelitian, Lemlit Unmer, Malang 